\title{
How US wages effect post-socialist European stock markets: An empirical study
}

\author{
Deniz Ilalan* \\ Department of Banking and Finance, Çankaya University, Turkey
}

Received: 19 September 2018

Revised: 3 November 2018

Accepted: 5 November 2018

\begin{abstract}
Following the famous tapering speech of Bernanke on 2013, US non-farm payroll data became the leading indicator for the monetary policy of Fed. After midst of 2014 Fed shifted its attention to average hourly wage increases which was regarded as the determinant of inflation. As inflation is closely linked with possible increments of Fed funds rate, investors began to follow US wages more closely. We investigate the impact of US wages especially through concentrating on some Post-Socialist European stock markets. As US wages are found to Granger cause these stock exchanges, interestingly with domestic wages, a similar causation relation could not be achieved. This brings out the question whether wages are indeed an indicator for stock markets or not.
\end{abstract}

Keywords: wages; post-socialist economies, stock markets, Granger causality JEL Classification Codes: E24, E44, E58, C58

\section{Introduction}

In the aftermath of the 2008 world financial crisis, US Federal Reserve (Fed) launched an extreme expansionary monetary policy program called quantitative easing $(\mathrm{QE})$. The balance sheet of Fed had ballooned from $\$ 900$ billion to $\$ 4.5$ trillion after the implementation of 3 rounds of bond-purchasing until 2015. During QE period, there has been a huge flow of money from developed markets to emerging and transition ones.

On May 22, 2013, however, Chairman Bernanke raised the possibility of tapering in his testimony to the congress which had a sharp negative impact on economic and financial conditions in emerging markets (Eichengreen and Gupta 2015). Further improvements would render an increase in the Fed funds rates as well. The reason for this controversial policy change was due to the fact that the developments in the US labor market, if continued, might be a good reason to terminate QE since it would reach its final goal. After this blockbuster announcement, the

\footnotetext{
*E-mail: denizilalan@cankaya.edu.tr.

Citation: Ilalan, D. (2018) How US wages effect post-socialist European stock markets: An empirical study, Economics and Business Letters, 7(4), 180-189.
} 
US non-farm payroll (NFP) data became an important indicator for financial markets throughout the world.

On December 18, 2013, Fed said it would reduce its purchases of treasury and mortgagebacked securities by $\$ 10$ billion a month beginning in January 2014. In a news conference, Chairman Ben Bernanke, said he expects the Federal Open Market Committee (FOMC) to take "further measured steps at future meetings" to reduce the program, which began in September 2012. Bernanke, speaking at what is likely to be his last news conference before handing over the post to current Vice Chair Janet Yellen, said the FOMC had "seen meaningful, cumulative progress in the labor market". On January 6, 2014, Janet Yellen was confirmed as chair of the Federal Reserve.

The Jackson Hole speech of Yellen on August 22, 2014 is of particular interest. In her speech she said: "... inflation has fallen short of our 2 percent objective while the labor market, until recently, operated very far from any reasonable definition of maximum employment" and "over the past several years, wage inflation, as measured by several different indexes, has averaged about 2 percent, and there has been little evidence of any broad-based acceleration in either wages or compensation. Indeed, in real terms, wages have been about flat, growing less than labor productivity. This pattern of subdued real wage gains suggests that nominal compensation could rise more quickly without exerting any meaningful upward pressure on inflation. And, since wage movements have historically been sensitive to tightness in the labor market, the recent behavior of both nominal and real wages point to weaker labor market conditions than would be indicated by the current unemployment rate". After this speech, investors began to pay more attention to average hourly US wage increases.

Although financial markets attribute too much importance to US wage increases and deem it as a precursor for stock returns, due to its recency the literature regarding the relationship between US wages and world stock markets is quite shallow. Yet, studies regarding these issues are usually conducted with domestic wages and domestic stock returns. In addition, wages are not treated separately, usually accompanied with unemployment rate or taken as a determinant of unemployment. The literature is polyphonic since a consensus has not been reached whether stock markets lead to unemployment or that unemployment is a predictor of stock market (Boyd et al., 2005). Farmer $(2013,2015)$ demonstrated evidence that stock prices are a predictor of unemployment rate in the US. Fritsche and Pierdzioch, (2016) and Arestis, Baddeley, and Sawyer, (2007) also found that the stock market is an important indicator of unemployment and wages in Germany. Farsio and Fazel (2013), on the other hand, did not encounter any causal relationship between unemployment and stock markets in China, the US, and Japan. The literature mainly concentrates on developed countries, especially US with a dearth for emerging and transition economies. In a recent study by Pan (2018) the relationship between the stock market and unemployment in 30 advanced and 11 developing and emerging countries is examined and it is shown that unemployment rate and stock prices are co-integrated in all country groups and there was causality between stock prices and unemployment. For the 11 developing and emerging countries, the causality test results indicated a strong Granger causality from unemployment to stock prices and results for developing and emerging countries suggest that the unemployment rate can help to forecast stock prices, but not vice versa. Baker et al. (2012) considered 6 developed stock markets for an annual data from 1980 and 2005 and demonstrate that investor sentiment is a significant predictor of country-level returns. They took volatility premium, initial public offering and turnovers as proxies. Singh et al. (2010), on the other hand, took a data ranging from 2000 to 2008 for 15 North American, European and Asian markets through concentrating on opening and closing prices. They came up with the conclusion that there is a contamination effect between some markets in the form of volatility spillovers.

Our study differs from these two in certain aspects. First we took a very recent data from 2010 to 2018 in order to measure the effect of particularly average hourly wage increases of US 
non-farm payroll data on Post Socialist European stock indexes. As wage increases are deemed as a proxy for inflation and pinpointed by Fed officials, they are regarded as the leading indicator for possible increments of Fed funds rate. In that respect, this will foster a capital inflow to US markets. Thus we measure a direct effect coming from monetary policy of Fed rather than sentimental judgments.

However, studies regarding the interdependence among US wages and developing stock markets are almost nil. Moreover, to the best of our knowledge a comparative study regarding the effects of both US and national wage rates on Post-Socialist European stock markets has never been explored before. Following the arguments above, this study aims to investigate the impact of US wages on some Post-Socialist European stock markets. We consider four different PostSocialist European countries namely Latvia, Slovak Republic, Slovenia and Hungary. None of these countries with similarities but distinct characteristics resisted transition. As Lavigne (1995) pointed out, Hungary was the first country who made steps on the way the market economy even under communism. Slovenia, on the other hand, the rich country of former Yugoslavia, decided not to contribute to the development of poor members of the state and declared its independence in June 1991. A normal transition to the market economy could only be initiated by Slovenia beginning from 1992. Slovak Republic, was a surprise last case of a split. Indeed, the Czech-Slovak break-up is a good example of disintegration in the transition process. Yet, pre-war Czechoslovakia was one of the few examples of democracy in Central Europe. The Baltic countries, were a special case as they had lost their independence much later than the rest of the Empire. They all declared their independence on August 1991. Latvia, on the other hand, has the highest trading volume among them.

Hence, we intentionally choose these countries for our study as they have significant differences and operating a stock market with high volume compared to other shallow Post-Socialist European stock markets. In addition, the local wage data pertaining to these countries is much enhanced and longer than the others. We investigate the possible causation relationship between US and domestic wages and the stock markets of the countries in question. We found controversial results in the sense that US wages one-way Granger cause the stock exchanges whereas there seems no causation in either direction with the local wages. This brings out the fact that domestic wages do not possess any indication regarding the forecasting issues of domestic stock markets. However, as we have witnessed a one-way causality between US wages and these stock exchanges this shows that the causation indeed arises from the importance attributed to US wages by Fed such that it became a main determinant of US monetary policy. Therefore, one should be cautious in interpreting these results in the sense that US wages Granger cause Post-Socialist European stock markets not due to the intrinsic characteristics of wages but the fact that it is pinpointed with a forward guidance from Fed as a determinant of its monetary policy. Hence, we can say that US wages have an indirect causation on these stock markets.

The data, methodology and results are explained in Section 2 and Section 3 concludes.

\section{Data, methodology, and results}

We use a recent monthly data beginning from January 2010 to March 2018 for both wages and stocks. For the ease of scaling we took the natural logarithm of all series. The particular choice of year 2010 has two reasons. Firstly, our data source pertaining to wages, namely Fed St. Louis took it as the basis year. Secondly, as we aim to quantify the relationship between wages and stock returns in the aftermath of 2008 crisis, especially after the initiation of QE program our selection purpose becomes clearer. The corresponding monthly stock returns are retrieved from Bloomberg. Wages and stocks are depicted in Figures 1 and 2 respectively. 
Figure 1. Natural logarithm of monthly wages between 2010-2018 (from left to right United States, Slovak Republic, Slovenia, Latvia, and Hungary).

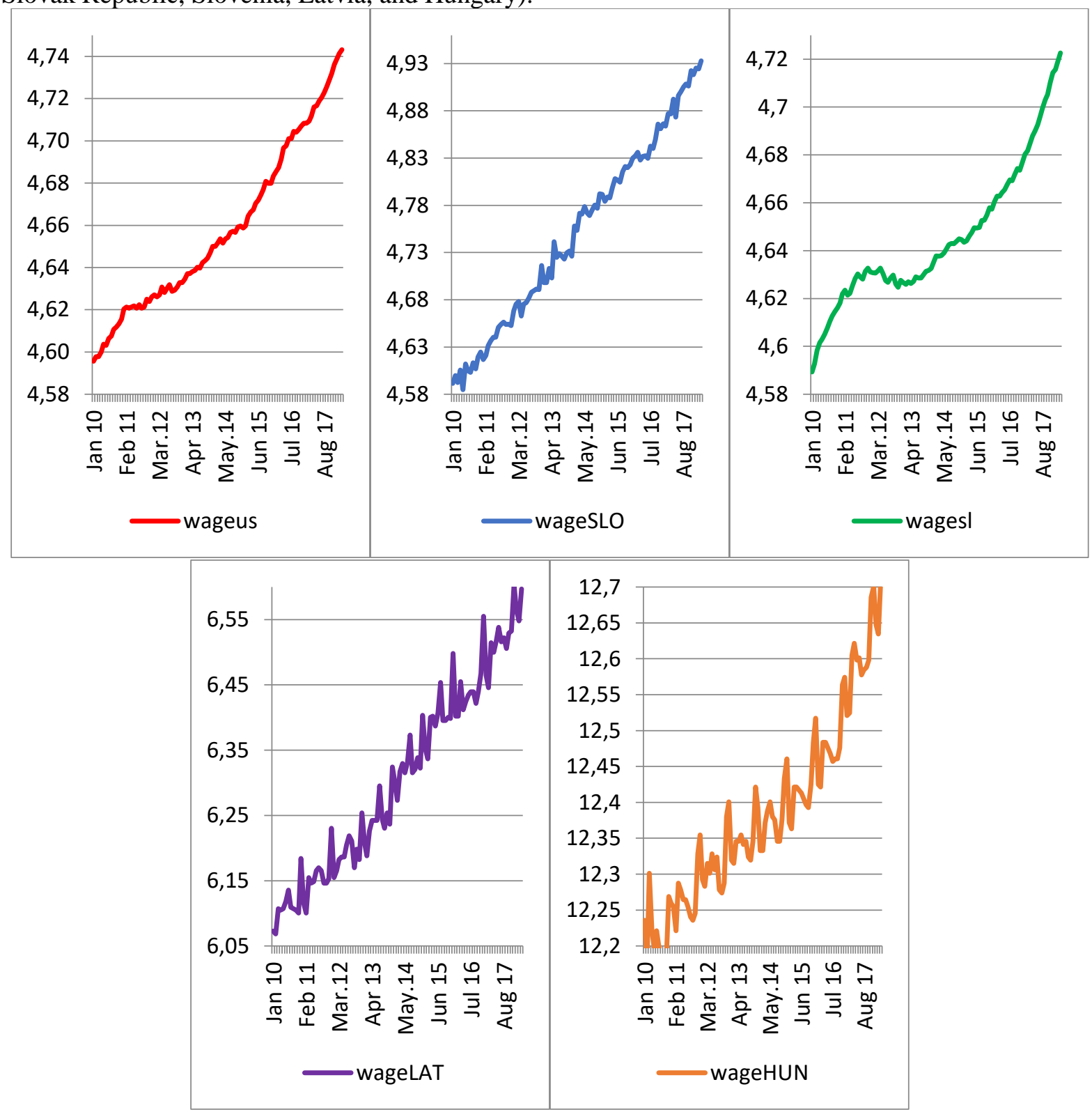

Our aim is to investigate causality between wages and stock exchanges. For doing this, we must first determine the order of integration. We present stationarity results via the application of ADF test (Dickey and Fuller, 1979, 1981) for wages and stocks in Tables 1 and 2 respectively. A summary of orders of integration is given in Table 3.

Table 1. ADF test results for wages.

\begin{tabular}{|c|c|c|c|c|c|c|}
\hline \multirow[b]{2}{*}{ Country } & \multicolumn{2}{|c|}{ No trend, no constant } & \multicolumn{2}{|c|}{ Constant, no trend } & \multicolumn{2}{|c|}{ Trend, constant } \\
\hline & Level & $1^{\text {st }}$ diff. & Level & $1^{\text {st }}$ diff. & Level & $1^{\text {st }}$ diff. \\
\hline US & 9.07 & -1.50 & 2.45 & $-10.32 * * *$ & 0.32 & $-11.02 * * *$ \\
\hline Latvia & 6.15 & -0.70 & 2.58 & $-3.14 * *$ & -1.24 & $-3.59 * *$ \\
\hline Slovak R. & 6.00 & $-14.91 * * *$ & 0.47 & $-18.41 * * *$ & $-4.33 * * *$ & $-18.38 * * *$ \\
\hline Slovenia & 1.14 & -0.93 & 1.98 & -2.04 & -0.55 & -2.20 \\
\hline Hungary & 5.76 & -0.65 & 5.91 & -2.00 & 5.10 & -3.09 \\
\hline
\end{tabular}


Figure 2. Natural logarithm of stock exchanges between 2010-2018 (from left to right United States, Slovak Republic, Slovenia, Latvia, and Hungary).

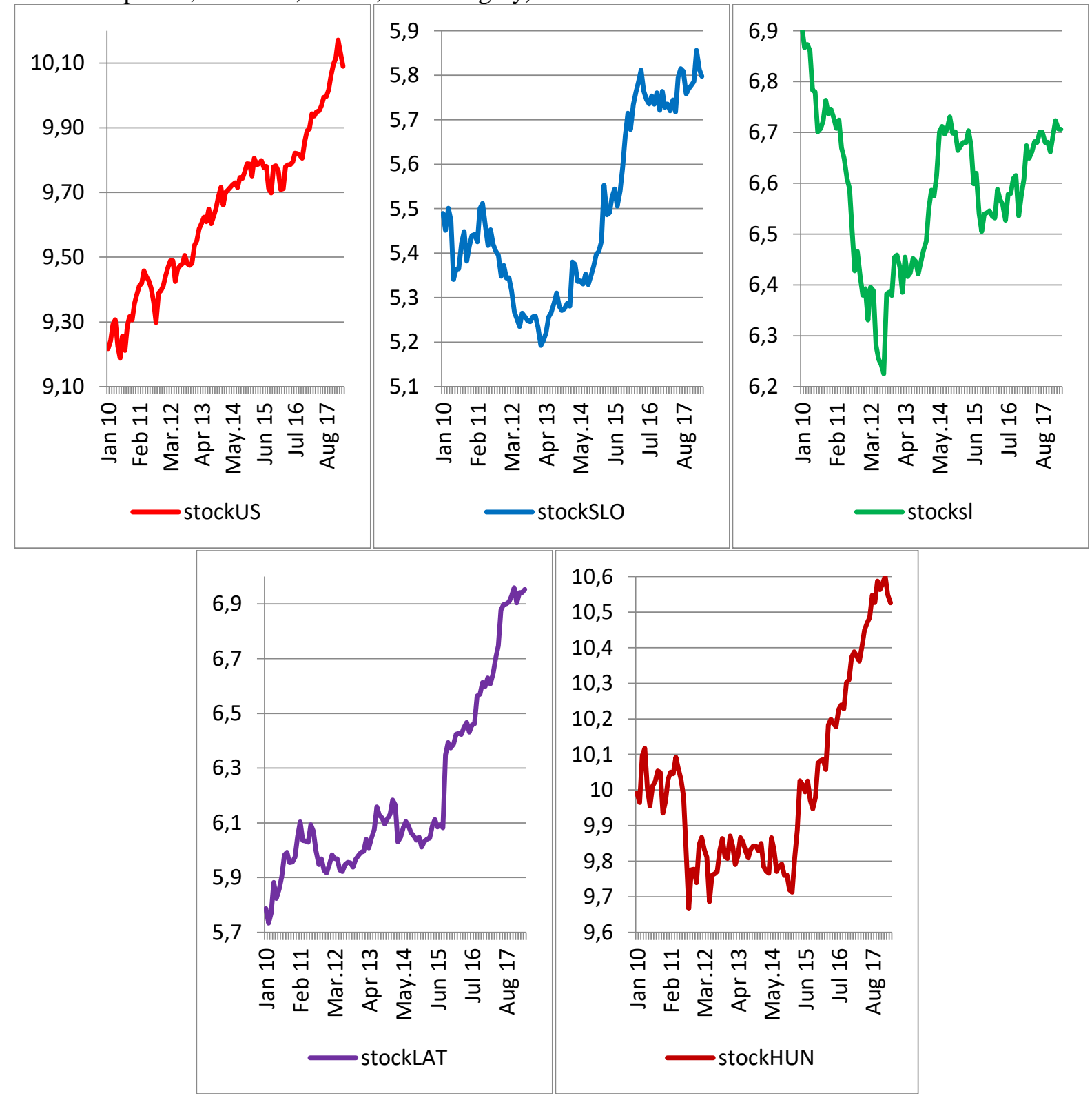

Table 2. PP test results for wages.

\begin{tabular}{lrrrrrr}
\hline \hline & \multicolumn{2}{c}{ No trend, no constant } & \multicolumn{3}{c}{ Constant, no trend } & \multicolumn{2}{c}{ Trend, constant } \\
Country & Level & \multicolumn{1}{c}{$1^{\text {st }}$ diff. } & \multicolumn{2}{c}{ Level } & \multicolumn{1}{c}{$1^{\text {st }}$ diff. } & \multicolumn{2}{c}{ Level } & \multicolumn{1}{c}{$1^{\text {st }}$ diff. } \\
\hline US & 8.09 & $-7.09^{* * *}$ & 2.52 & $-10.38^{* * *}$ & 0.3735 & $-10.95^{* * *}$ \\
Latvia & 3.72 & $-16.78^{* * *}$ & -0.11 & $-59.27 * * *$ & $-8.49 * * *$ & $-80.44^{* * *}$ \\
Slovak R. & 11.75 & $-13.81^{* * *}$ & 0.96 & $-26.45^{* * *}$ & $-7.54 * * *$ & $-29.01^{* * *}$ \\
Slovenia & 5.02 & $-4.38^{* * *}$ & 1.65 & $-6.35^{* * *}$ & 0.64 & $-6.62 * * *$ \\
Hungary & 3.23 & $-10.71^{* * *}$ & 0.07 & $-16.77^{* * *}$ & $-4.76^{* * *}$ & $-18.15^{* * *}$ \\
\hline \hline
\end{tabular}

As at least one of the series is integrated we will be following Toda and Yamomato (1995) procedure in order to test for Granger causality. 
Table 3. ADF test results for stock exchanges.

\begin{tabular}{lrrrrrr}
\hline \hline & \multicolumn{2}{c}{ No trend, no constant } & \multicolumn{2}{c}{ Constant, no trend } & \multicolumn{2}{c}{ Trend, constant } \\
Country & Level & \multicolumn{1}{c}{$1^{\text {st }}$ diff. } & \multicolumn{2}{c}{ Level } & \multicolumn{1}{c}{$1^{\text {st }}$ diff. } & \multicolumn{2}{c}{ Level } & $1^{\text {st }}$ diff. \\
\hline US & 2.60 & $-9.91^{* * *}$ & -0.62 & $-10.57 * * *$ & -3.09 & $-10.52^{* * *}$ \\
Latvia & 2.51 & $-9.06^{* * *}$ & 0.54 & $-9.62 * * *$ & -1.04 & $-9.66^{* * *}$ \\
Slovak R. & 0.80 & $-10.72^{* * *}$ & -0.31 & $-10.77 * * *$ & -1.99 & $-10.92^{* * *}$ \\
Slovenia & -0.54 & $-9.89 * * *$ & -2.19 & $-9.85 * * *$ & -2.33 & $-10.13 * * *$ \\
Hungary & 0.97 & $-9.09 * * *$ & -0.15 & $-9.13 * * *$ & -1.42 & $-9.27 * * *$ \\
\hline \hline
\end{tabular}

Note. $* * * * * *$ stand for $10 \%, 5 \%, 1 \%$ significance levels respectively

Table 4. Order of integration.

\begin{tabular}{lrr}
\hline \hline Country & Wage & Stock \\
\hline US & 1 & 1 \\
Latvia & 1 & 1 \\
Slovak R. & 1 & 1 \\
Slovenia & 1 & 1 \\
Hungary & 1 & 1 \\
\hline \hline
\end{tabular}

Table 5. Optimal lags.

\begin{tabular}{lccccc}
\hline \hline $\begin{array}{l}\text { Wage } \\
\text { Stock }\end{array}$ & \multicolumn{1}{c}{ US } & Latvia & Slovak R. & Slovenia & Hungary \\
\hline US & SC: 1 / AIC: 1 & SC: 1 / AIC: 1 & SC: 1 / AIC: 1 & SC: 1 / AIC: 1 & SC: 1 / AIC: 1 \\
Latvia & & SC: 3 / AIC:6 & & & \\
$\begin{array}{l}\text { Slovak } \\
\text { R. }\end{array}$ & & SC: 2 / AIC: 2 & & \\
$\begin{array}{l}\text { Slovenia } \\
\text { Hungary }\end{array}$ & & & SC: 1 / AIC: 6 & \\
\hline \hline
\end{tabular}

Note. SC: Schwarz Information Criterion, AIC: Akaike Information Criterion.

Now we look for optimal lag lengths between wages and stock exchanges since VAR models are very sensitive to the lag length of variables used in equations. Lag lengths are set with respect to Schwarz Information Criterion (SC) and Akaike Information Criterion (AIC). We take the maximum of the results of these two. The optimal lags are displayed in Table 4.

For precluding inefficiency issues we test for the serial correlation of residuals. Table 5 stands for the results of the LM test for serial correlation. We deduce that for $5 \%$ significance level there are 3 problematic cases. The first one is US wages and US stock which is redundant as optimal lag is 1 . However, for US wages and Latvian stocks the serial correlation has to be removed via increasing the lag to 8 and similarly for Hungary wages and stocks the appropriate lag is 6 .

We can now apply Granger causality tests. The results are shown in Table 6. Appropriate lags are indicated. Notice that the causality test is applied through adding a lag based on the order of information as required by Toda-Yamomato approach.

We see that US wages Granger cause US and Latvia stock exchanges with 5\% and Slovak Republic, Slovenia, Hungary stock exchanges with 10\% significance level. We could not be able to find any evidence of causation for the opposite direction. In addition there is no causation in either way for the domestic wages and domestic stock exchanges for Latvia, Slovak Republic, Slovenia and Hungary. 
Table 6. P-value of the serial correlation of residuals.

\begin{tabular}{lcccccccccr}
\hline \hline Lag- & US/ US & \multirow{2}{*}{ US/L. } & $\begin{array}{c}\text { US / } \\
\text { W/S }\end{array}$ & SS / Slo & $\begin{array}{r}\text { US / } \\
\text { Hun }\end{array}$ & L. /L. & $\begin{array}{r}\text { S.R. / } \\
\text { S.R. }\end{array}$ & $\begin{array}{r}\text { Slo / } \\
\text { Slo }\end{array}$ & $\begin{array}{r}\text { Hun / } \\
\text { Hun }\end{array}$ \\
\hline 1 & $\mathbf{0 . 9 6 5 6}$ & 0.6012 & 0.3240 & 0.8971 & 0.0575 & 0.0001 & 0.2232 & 0.0001 & 0.0000 \\
2 & 0.9102 & 0.4039 & 0.2618 & 0.9164 & 0.1847 & 0.0001 & 0.2256 & 0.0003 & 0.0000 \\
3 & 0.2015 & 0.1199 & 0.5406 & 0.1065 & 0.2824 & 0.2931 & 0.6365 & 0.0621 & 0.1766 \\
4 & 0.3663 & 0.7131 & 0.4283 & 0.2589 & 0.9036 & 0.0225 & 0.3921 & 0.4132 & 0.4073 \\
5 & 0.3893 & 0.0616 & 0.0648 & 0.1563 & 0.0222 & 0.3900 & 0.2165 & 0.0109 & 0.8245 \\
6 & 0.8236 & 0.4038 & 0.5734 & 0.3230 & 0.6012 & 0.0477 & 0.8978 & 0.3303 & $\mathbf{0 . 9 9 1 3}$ \\
7 & 0.1783 & 0.8744 & 0.4232 & 0.0054 & 0.0192 & 0.3011 & 0.2572 & 0.0202 & 0.6237 \\
8 & 0.9573 & $\mathbf{0 . 9 5 8 7}$ & 0.3532 & 0.6602 & 0.6189 & 0.2201 & 0.8931 & 0.2048 & 0.0655 \\
9 & 0.9057 & 0.7775 & 0.3948 & 0.4245 & 0.2317 & 0.3848 & 0.2445 & 0.4396 & 0.2087 \\
10 & 0.3580 & 0.4265 & 0.5145 & 0.4090 & 0.6430 & 0.0035 & 0.2483 & 0.4079 & 0.0010 \\
\hline \hline
\end{tabular}

Note. W: Wage, S: Stock Index, US: United States, L: Latvia, S.R.: Slovak Republic, Slo: Slovenia, Hun: Hungary

Table 7. Granger causality results.

\begin{tabular}{lrrr}
\hline \hline Null Hypothesis & Lag & Chi-sq. stat. & p-value \\
\hline US wage does not Granger cause US stock & 1 & 6.644 & $0.036^{* *}$ \\
US stock does not Granger cause US wage & 1 & 0.642 & 0.725 \\
US wage does not Granger cause Latvia stock & 8 & 16.814 & $0.019^{* *}$ \\
Latvia stock does not Granger cause US wage & 8 & 4.974 & 0.663 \\
US wage does not Granger cause Slovak R. stock & 1 & 5.448 & $0.066^{*}$ \\
Slovak R. stock does not Granger cause US wage & 1 & 3.830 & 0.147 \\
US wage does not Granger cause Slovenia stock & 1 & 5.374 & $0.068^{*}$ \\
Slovenia stock does not Granger cause US wage & 1 & 1.773 & 0.412 \\
US wage does not Granger cause Hungary stock & 1 & 4.815 & $0.090^{*}$ \\
Hungary stock does not Granger cause US wage & 1 & 2.799 & 0.247 \\
Latvia wage does not Granger cause Latvia stock & 6 & 6.655 & 0.354 \\
Latvia stock does not Granger cause Latvia wage & 6 & 7.900 & 0.246 \\
Slovak R. wage does not Granger cause Slovak R. stock & 2 & 2.308 & 0.315 \\
Slovak R. stock does not Granger cause Slovak R. wage & 2 & 1.594 & 0.451 \\
Slovenia wage does not Granger cause Slovenia stock & 6 & 7.702 & 0.261 \\
Slovenia stock does not Granger cause Slovenia wage & 6 & 6.049 & 0.417 \\
Hungary wage does not Granger cause Hungary stock & 6 & 6.176 & 0.458 \\
Hungary stock does not Granger cause Hungary wage & 6 & 4.071 & 0.299 \\
\hline \hline
\end{tabular}

We apply Johansen co-integration test in order to validate our findings pertaining to Granger causality tests.

In addition, we divide our data to 2 sub-samples to check whether the rank of co-integrating vectors is consistent.

Finally, it is natural to assume that the causation relation might be driven by other factors. Here we follow Farmer (2015) and we took into consideration the US GDP, CPI and PCE as other possible and sensible macroeconomic variables for robustness check. For monthly GDP, we used cubic spline method and interpolated monthly values. We found out that these variables do not have a significant causal relationship with the relevant stocks in question. 
Table 8. Johansen co-integration test results together with sub-samples.

\begin{tabular}{|c|c|c|c|}
\hline Series (with US wage) & Hypothesized number & Trace stat. & $\overline{p \text {-value }}$ \\
\hline \multirow[t]{2}{*}{ US stock } & None & 25.8721 & $0.0359 * *$ \\
\hline & At most 1 & 12.5179 & 0.3829 \\
\hline \multirow[t]{2}{*}{ US stock I } & None & 15.4947 & $0.0103 * *$ \\
\hline & At most 1 & 3.8417 & 0.1981 \\
\hline \multirow[t]{2}{*}{ US stock II } & None & 21.7186 & $0.0313 * *$ \\
\hline & At most 1 & 2.2087 & 0.7359 \\
\hline \multirow[t]{2}{*}{ Latvia stock } & None & 15.2767 & $0.0539 *$ \\
\hline & At most 1 & 1.2836 & 0.2572 \\
\hline \multirow[t]{2}{*}{ Latvia stock I } & None & 27.2130 & $0.0047 * * *$ \\
\hline & At most 1 & 7.4533 & 0.1045 \\
\hline \multirow[t]{2}{*}{ Latvia stock II } & None & 23.6601 & $0.0920 *$ \\
\hline & At most 1 & 7.4372 & 0.3011 \\
\hline \multirow{2}{*}{ Slovak Rep. stock } & None & 25.4373 & $0.0565^{*}$ \\
\hline & At most 1 & 12.5180 & 0.2025 \\
\hline \multirow[t]{2}{*}{ Slovak Rep. stock I } & None & 12.6945 & $0.0433 * *$ \\
\hline & At most 1 & 1.2941 & 0.2982 \\
\hline \multirow[t]{2}{*}{ Slovak Rep. stock II } & None & 22.1863 & $0.0269 * *$ \\
\hline & At most 1 & 2.9032 & 0.5989 \\
\hline \multirow[t]{2}{*}{ Slovenia stock } & None & 20.2618 & $0.0058 * * *$ \\
\hline & At most 1 & 9.1645 & 0.1134 \\
\hline \multirow[t]{2}{*}{ Slovenia stock I } & None & 12.6472 & $0.0441 * *$ \\
\hline & At most 1 & 2.1875 & 0.1641 \\
\hline \multirow[t]{2}{*}{ Slovenia stock II } & None & 20.1230 & $0.0522 *$ \\
\hline & At most 1 & 2.7841 & 0.6218 \\
\hline \multirow[t]{2}{*}{ Hungary stock } & None & 26.3121 & $0.0441 * *$ \\
\hline & At most 1 & 12.5180 & 0.1950 \\
\hline \multirow[t]{2}{*}{ Hungary stock I } & None & 28.5911 & $0.0147 * *$ \\
\hline & At most 1 & 8.2605 & 0.4689 \\
\hline \multirow[t]{2}{*}{ Hungary stock II } & None & 31.8660 & $0.0079 * * *$ \\
\hline & At most 1 & 9.4634 & 0.1537 \\
\hline
\end{tabular}

Note. $*, * *, * * *$ stand for $10 \%, 5 \%, 1 \%$ significance levels respectively

\section{Conclusion}

In this study we aim to understand whether US wages can be regarded as an indicator for transition stock markets. The rationale behind our approach is due to the reason that US wages are deemed as one of the most important data for inflation rates by Fed. As inflation will foster increases in Fed funds rate, this will render an outflow of money from emerging and transition markets. We concentrated on Post-Socialist European stock markets as they are interesting examples of economies of transition from socialist economy to market economy.

Our findings indicate that US wages one way Granger cause stock exchanges of Latvia, Slovak Republic, Slovenia and Hungary. However, we could not be able to encounter a statistically significant causation in either direction for domestic wages. This demonstrates that domestic wages do not intrinsically Granger cause stock exchanges. Yet, it turned out that US wages Granger cause Post-Socialist European stock exchanges as Fed regards them as a leading indicator for the determination of its monetary policy. Thus we can conclude that US wages can help investors for better forecasting of stock exchanges. 
Table 9. Robustness check.

\begin{tabular}{lrrr}
\hline Null Hypothesis & Lag & Chi-sq. stat. & p-value \\
\hline US GDP does not Granger cause US stock & 8 & 3.867 & 0.145 \\
US GDP does not Granger cause Hungary stock & 8 & 2.206 & 0.332 \\
US GDP does not Granger cause Latvia stock & 8 & 4.242 & 0.120 \\
US GDP does not Granger cause Slovak R. stock & 8 & 4.456 & 0.108 \\
US GDP does not Granger cause Slovenia stock & 8 & 0.306 & 0.858 \\
US CPI does not Granger cause US stock & 2 & 0.153 & 0.926 \\
US CPI does not Granger cause Hungary stock & 2 & 1.526 & 0.466 \\
US CPI does not Granger cause Latvia stock & 2 & 1.457 & 0.483 \\
US CPI does not Granger cause Slovak R. stock & 2 & 2.791 & $0.095^{*}$ \\
US CPI does not Granger cause Slovenia stock & 2 & 0.208 & 0.901 \\
US PCE does not Granger cause US stock & 6 & 0.831 & 0.660 \\
US PCE does not Granger cause Hungary stock & 5 & 3.642 & 0.162 \\
US PCE does not Granger cause Latvia stock & 1 & 1.927 & 0.382 \\
US PCE does not Granger cause Slovak R. stock & 1 & 3.897 & 0.143 \\
US PCE does not Granger cause Slovenia stock & 1 & 3.839 & 0.147 \\
\hline \hline
\end{tabular}

\section{References}

Arestis, P., Baddeley, M., and Sawyer, M. (2007) The relationship between capital stock, unemployment and wages in nine EMU countries, Bulletin of Economic Research, 59(2), $125-148$.

Baker, M., Wurgler, J., and Yuan, Y. (2012) Global, local, and contagious investor sentiment. Journal of Financial Economics, 104(2), 272-287.

Boyd, J., Hu, J., and Jagannathan, R. (2005) The Stock Market's Reaction to Unemployment News: Why Bad News Is Usually Good for Stocks, Journal of Finance, 60(2), 649-672.

Dickey, D. A., and Fuller, W. A. (1979) Distribution of the estimators for autoregressive time series with a unit root, Journal of the American Statistical Association, 74(366), 427-431.

Dickey, D. A., and Fuller, W. A. (1981) Likelihood Ratio Statistics for Autoregressive Time Series with a Unit Root, Econometrica, 49(4), 1057-1072.

Eichengreen, B., and Gupta, P. (2004) Tapering Talk: The Impact of Expectations of Reduced Federal Reserve Security Purchases on Emerging Markets, World Bank Policy Research Working Paper No. 6754.

Granger, C. W. J. (1969) Investigating Causal Relations by Econometric Models and Crossspectral Methods, Econometrica, 37(3), 424-438.

Farmer, R .E. A. (2013) Animal spirits, financial crises and persistent unemployment", Economic Journal, 123(58), 317-340.

Farmer, R. E. A. (2015) The stock market crash really did cause the Great Recession, Oxford Bulletin of Economics and Statistics, 77(5), 617-633.

Farsio, F., and Fazel, S. (2013) The stock market / unemployment relationship in USA, China and Japan, International Journal of Economics and Finance, 5(3), 351-360.

Fritsche, U., and Pierdzioch, C. (2016) Animal spirits, the stock market, and the unemployment rate: Some evidence for German data, Macroeconomics and Finance Series 201601, University of Hamburg, Department of Socioeconomics.

Lavigne, M. (1995) The Economics of Transition: From Socialist Economy to Market Economy, St. Martin's Press.

Pan, W. (2018) Does the stock market really cause unemployment? A cross-country analysis, North American Journal of Economics and Finance, 44, 34-43. 
Rigobon, R., and Sack, B. (2003) Measuring the Reaction of Monetary Policy to the Stock Market, Quarterly Journal of Economics, 118(2), 639-669.

Singh, P., Kumar, B., and Pandey, A. (2010) Price and volatility spillovers across North American, European and Asian stock markets, International Review of Financial Analysis, 19(1), 55-64.

Toda, H. Y., and Yamamoto T. (1995) Statistical Inferences In Vector Autoregressions With Possibly Integrated Processes, Journal of Econometrics, 66, 225-250. 